\title{
MEASUREMENT OF THE BRONCHIAL MUCOUS GLAND LAYER: A DIAGNOSTIC YARDSTICK IN CHRONIC BRONCHITIS *
}

\author{
BY \\ LYNNE REID \\ From the Institute of Diseases of the Chest and Brompton Hospital, London
}

(RECEIVED FOR PUBLICATION DECEMBER 17, 1959)

An increase in the thickness of mucous glands and in the size of the acini which compose them is a recognized feature of chronic bronchitis (Reid, 1958b), but the degree of hypertrophy which occurs has not hitherto been measured. If such increase could be readily measured, found to be constant in its relation to the presence of the disease, distinguishable from the normal and perhaps found to vary with clinical severity, a useful criterion for the pathological diagnosis of chronic bronchitis would be available. This paper describes studies which were directed to establishing such a yardstick. Although goblet cells in the epithelium also are increased (Florey, Carleton, and Wells, 1932 ; Reid, 1954), it was decided to concentrate on glands rather than goblet cells, not only because volumetrically they are much the more significant (normally about $\mathbf{4 0}$ times as great, see Appendix A), but because, especially in necropsy material, the glands are intact while the epithelium may be damaged, precluding any count of goblet cells which, furthermore, may be so clumped in islands that their distribution may vary considerably even over small areas.

Chronic bronchitis and emphysema as seen in Great Britain are usually considered to be more frequent and serious than in other countries; to some extent this may be due to difference in nomenclature which a quantitative measurement of increase in gland thickness may help to dispel by making possible a more objective assessment of the condition both here and overseas. In particular, it might explain the difference in emphasis given to the aetiological role of chronic bronchitis in relation to emphysema, and to reconcile the use of the terms "asthma" and "chronic bronchitis," in the United States and Great Britain.

*The statistical analysis entailed in this study is the work of $B$ Benjamin, Ph.D., F.I.A
The questions which had to be answered and which set the course of this investigation were:

(1) In chronic bronchitis is the increase in the thickness of the gland layer constant?

(2) What is the relation of this increase to the normal thickness ?

(3) How do chronic bronchitis, bronchiectasis, and emphysema without sputum compare in this respect?

(4) Is there any general relation between increase in gland layer and sputum production?

To answer these questions a group of bronchi from subjects in whom chronic bronchitis was diagnosed clinically was compared with normal bronchi. For comparison a smaller group from cases of bronchiectasis and emphysema without sputum was also studied. A clear distinction was found between normal bronchi and bronchi from subjects with chronic bronchitis, all the latter being cases in which the duration and severity of the disease left no doubt of the clinical diagnosis. As it seemed likely that lesser amounts of sputum than produced by this group were also abnormal, 9 a further series of bronchi from random operation specimens was examined to correlate lesser degrees of sputum production and gland thickness.

\section{MATERIAL}

The details of the number of bronchi used and the $C$ age and sex of the patients from whom they were obtained are given in Table I, together with the type of bronchus and the source of the specimen.

ConTrols.-This group is more truly called $\stackrel{\oplus}{+}$ " controls" than normal bronchi. They come from $\frac{7}{0}$ a group of subjects who had not habitually produced sputum ; in addition to normal subjects they probably $\stackrel{\mathbb{Q}}{\Phi}$ include some who, while not producing sputum, $\overrightarrow{\mathbb{Q}}$ might still have some gland hypertrophy. Two at least had no pulmonary disease and could be considered normal: one a man of 45 who had died $\delta$ 
TABLE I

MATERIAL STUDIED

\begin{tabular}{|c|c|c|c|c|c|c|c|c|c|c|c|c|}
\hline & \multirow[b]{2}{*}{$\begin{array}{l}\text { No. of } \\
\text { Cases }\end{array}$} & \multirow[b]{2}{*}{$\begin{array}{l}\text { No. of } \\
\text { Bronchi }\end{array}$} & \multirow[b]{2}{*}{$\begin{array}{c}\text { Average } \\
\text { Age }\end{array}$} & \multirow[b]{2}{*}{$\begin{array}{c}\text { Age } \\
\text { Range }\end{array}$} & \multirow[b]{2}{*}{$\begin{array}{l}\text { Opera- } \\
\text { tion }\end{array}$} & \multirow[b]{2}{*}{ Necropsy } & \multirow[b]{2}{*}{ Male } & \multirow[b]{2}{*}{ Female } & \multicolumn{4}{|c|}{ Type of Bronchus } \\
\hline & & & & & & & & & Main & Lobar & $\underset{\text { mental }}{\text { Seg- }}$ & $\underset{\text { Known }}{\text { Not }}$ \\
\hline 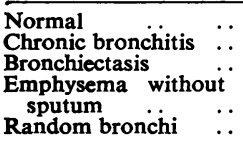 & $\begin{array}{r}7 \\
20 \\
7 \\
3 \\
37\end{array}$ & $\begin{array}{r}99 \\
25 \\
10 \\
4 \\
54\end{array}$ & $\begin{array}{l}34 \\
60 \\
35 \\
40 \\
56\end{array}$ & $\begin{array}{l}19-57 \\
50-88 \\
19-48 \\
37-46 \\
21-76\end{array}$ & $\begin{array}{r}6 \\
3 \\
7 \\
2 \\
37\end{array}$ & $\begin{array}{r}1 \\
17 \\
0 \\
1 \\
0\end{array}$ & $\begin{array}{r}6 \\
18 \\
5 \\
2 \\
33\end{array}$ & $\begin{array}{l}1 \\
2 \\
2 \\
1 \\
4\end{array}$ & $\begin{array}{r}3 \\
7 \\
1 \\
1 \\
13\end{array}$ & $\begin{array}{r}5 \\
11 \\
6 \\
3 \\
30\end{array}$ & $\begin{array}{r}1 \\
4 \\
3 \\
-7\end{array}$ & 4 \\
\hline
\end{tabular}

suddenly of coronary disease, the other a man of 57 whose right middle lobe was removed because of damage at operation for the removal of a mediastinal tumour. Among the other five were four cases of peripheral carcinoma and one of a non-cavitated tuberculous lesion.

Chronic Bronchitis.-Twenty-five bronchi from 20 subjects with chronic bronchitis were examined. Seventeen specimens were obtained at necropsy and three at operation; of the former nine were from patients who died from some other cause than chronic bronchitis or emphysema and in six cor pulmonale was included in the death certificate. The age range was 50 to 88, with an average of 60 . These were known to have had chronic bronchitis for a minimum of five years, usually with sputum daily all the year round, in some only during the winter, of a minimum of $1 \mathrm{oz}$. daily. Some produced as much as $5 \mathrm{oz}$. per day. In the whole group the clinical diagnosis was clear. These cases included some with clinical and pathological evidence of emphysema.

BRONCHIECTASIS.-Ten bronchi from seven operation specimens of bronchiectasis were studied, from patients whose average age was 35 , ranging from 19 to 48. Lungs from children were excluded. In all, bronchograms showed the characteristic deformity, although the reason for a resection in some was the persistence of sputum and recurrent infection, while in others it was haemoptysis.

EMPHYSEMA.-Three subjects with emphysema but no chronic bronchitis, i.e., no sputum, were included. In two the specimen was obtained at operation and one at necropsy. The average age was 40 , the range 37 to 46 . The number was small because only those without sputum were included.

Random Specimens.-Fifty-four bronchi from a group of 37 random operation specimens were examined in the same way. These were mostly cases of carcinoma, though they included a few of tuberculosis. A specimen was discarded if the bronchial stump was involved by tumour to within a centimetre. Operation was undertaken for carcinoma in 27 cases, in seven for bronchiectasis, in three for tuberculosis, and in one for oedema. According to the amount of sputum the patients were graded into half-ounce categories. The first category, i.e., up to half an ounce, was, however, divided to include "no sputum" and "a trace," in order to correlate small amounts of sputum and gland thickness. Cases were placed in the appropriate category mainly by reference to the amount of sputum measured in hospital, but also to the patient's account of his sputum history. The daily measurements were averaged; at least one week's measurements were possible in all cases and usually measurements were available for between two and four weeks. The year before operation was preferred to the few weeks immediately preceding if there was a discrepancy between them, so that, if a patient had produced half an ounce in the immediate pre-operative period but only a trace in the previous months and returned to a trace after operation, the measurements in his case were included in the "trace" group. Grouping was done in ignorance of and, therefore, regardless of bronchial measurements, which themselves were made irrespective of the grouping. Measurements of sputum produced are of necessity crude, and the relation of this to the total secretion produced uncertain, but it is felt that these inherent difficulties must not preclude an attempt to assess the sputum amount.

Of these cases some are included in the earlier groups: five in the controls, one in the chronic bronchitis, and six in the bronchiectasis.

\section{Methods}

MeAsurements.-Measurements were made on main and lobar bronchi, except for a few cases in which segmental bronchi were used (see Table I). The absolute thickness of the wall of these bronchi varies little, though because of reduction in the size of the lumen passing distally the thickness increases relatively to it. Sections were $5 \mu$ in thickness and three consecutive sections stained with haematoxylineosin stain, Verhoeff van Gieson, and periodic-acidSchiff methods respectively.

The measurements found most useful and on which the results are based are those indicated in Fig. 1: (i) The thickness of the gland layer as it lies between cartilage and epithelium, (A); (ii) the thickness of the bronchial wall (taken from the same point as (i)), i.e., from basement membrane of the epithelium to the inner aspect of the perichondrium, (B); as is shown in Table II, gland and wall thickness were expressed as a ratio; (iii) the total number of acini, complete or incomplete, in a higher-power microscopic field.

Bronchial glands lie between the epithelium and the cartilage and also between the plates of cartilage and 


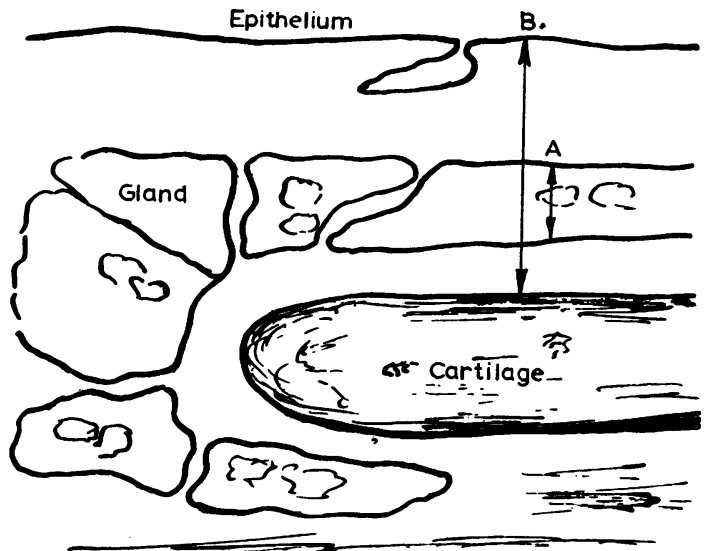

FIG. 1.-To illustrate measurements made on bronchial wall. B represents the internal thickness of wall, the distance between basement membrane of epithelium and inner aspect of cartilage, $A$, the thickness of the gland at the same point. Gland/wall ratio may be similar for a given bronchus although the thickness of measurements may vary.

external to them. At first, measurements were also made of the total depth of the gland and the thickness of the bronchial wall to its external limit. The internal layer was ultimately chosen, as the epithelium and inner aspects of the cartilage are clear-cut. The total thickness is not easily determined, particularly in the extrapulmonary bronchi, as the outer limit of the adventitia is often poorly defined or fragmented. At the beginning, in making measurements (i) and (ii), positions were chosen at which the cartilage surface was roughly parallel to the surface epithelium, but it was found that even at the ends of the plates of cartilage, where the edge turns away from the surface, although absolute measurements were greater, the ratio of wall to gland thickness remained the same Because it is less affected by a change in position along the wall the ratio has been used for detailed $\bar{p}$ statistical analysis rather than the thickness of the gland layer. For example, in the normal bronch bu where measurements were made at several positions in the wall the coefficient of variation (ratio of standard deviation to mean value) was $44 \%$ for thegland thickness but only $28 \%$ for the ratio. The्w ratio is therefore a more stable statistic. Measure ments were made to the basement membrane of the epithelium from the junction of cartilage and peri chondrium; where this had separated measurementr was made to midway between the two. The membranous portion of the main bronchus, beingw free of cartilage, was not used. The number of measurements made in any one bronchus varied; in a few there was only one, but in most, especially the bronchitics, two, and, occasionally, as many as six The average of the measurements was taken aફD representative of the particular bronchus.

Measurements were made by means of a graticules set in the eyepiece of the microscope. They were originally expressed in " graticule units," from which the ratios were estimated, but were later converted to millimetres. A $\times 6$ eyepiece was used, ${ }^{*}$ while for (i) and (ii), described above, a $16 \mathrm{~mm}$. objective anch for (iii) a $4 \mathrm{~mm}$. objective was used. This meant that the low-power field (16 mm. objective) was approximately 1.5 sq. $\mathrm{mm}$., while the high-power field $(4 \mathrm{~mm} \overrightarrow{\overline{0}}$ objective) was 0.36 sq. $\mathrm{mm}$.

One group of bronchi was examined on two occasions, another on three occasions, some weeks.

*The size of field may vary up to $20 \%$ for microscopes of different mariufacture, using eyepieces and objectives of the same standard음 designation.
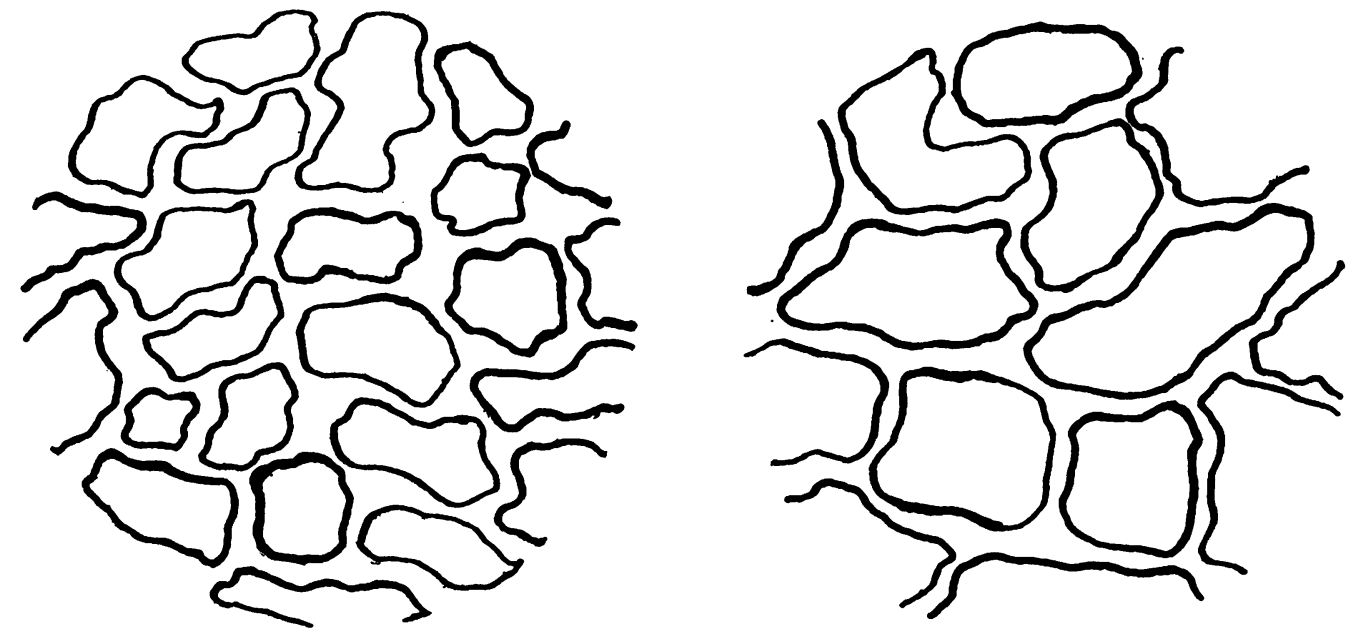

FIG. 2.-Acini in high-power field, $0.45 \mathrm{~mm}$. in diameter. At left from normal subject-24 acini included; at right from chronic bronchitic-14 acini. 
TABLE II

MEASUREMENTS OF MUCOUS GLANDS OF BRONCHI GROUPED ACCORDING TO CLINICAL DIAGNOSIS

\begin{tabular}{|c|c|c|c|c|c|c|c|c|c|c|}
\hline \multirow[b]{2}{*}{ Group } & & \multirow[b]{2}{*}{ Cases } & \multirow[b]{2}{*}{ Broncli } & \multicolumn{2}{|c|}{ Thickness of } & \multirow{2}{*}{$\begin{array}{c}\text { Mean } \\
\text { Gland Wall } \\
\text { Ratio and } \\
\text { Range }\end{array}$} & \multirow{2}{*}{$\begin{array}{l}\text { Standard } \\
\text { Error of } \\
\text { Mean } \\
\text { Ratio }\end{array}$} & \multirow{2}{*}{$\begin{array}{l}\text { Mean } \\
\text { Acini }\end{array}$} & \multirow{2}{*}{$\begin{array}{l}\text { Standard } \\
\text { Error of } \\
\text { Mean } \\
\text { Acini }\end{array}$} & \multirow{2}{*}{$\begin{array}{l}\text { Difference } \\
\text { from Normal }\end{array}$} \\
\hline & & & & $\begin{array}{l}\text { Wall } \\
\text { (mm.) }\end{array}$ & $\begin{array}{l}\text { Gland } \\
\text { (mm.) }\end{array}$ & & & & & \\
\hline Normal & $\cdots$ & 7 & 8 & 0.64 & $0 \cdot 17$ & $\begin{array}{c}0.26 \\
(0.14-0.36)\end{array}$ & 0.026 & 24 & 1.4 & \\
\hline Bronchitis $\ldots$ & . & 20 & 26 & $1 \cdot 07$ & 0.64 & $\begin{array}{c}0.59 \\
(0.41-0.79)\end{array}$ & 0.020 & 14 & 0.88 & $\begin{array}{l}\text { Significant } \\
\mathbf{P}=<0.001\end{array}$ \\
\hline Bronchiectasis & . & 7 & 10 & 0.93 & 0.52 & $\begin{array}{c}0.54 \\
(0.33-0.70)\end{array}$ & 0.048 & 16 & $1 \cdot 3$ & $\begin{array}{l}\text { Significant } \\
\mathbf{P}=<0.001\end{array}$ \\
\hline Emphysema & . & 3 & 4 & 0.68 & 0.23 & $\begin{array}{c}0.33 \\
(0.28-0.43)\end{array}$ & 0.046 & 24 & $2 \cdot 1$ & $\begin{array}{l}\text { Not significant } \\
\mathbf{P}=0.19\end{array}$ \\
\hline
\end{tabular}

apart, in order to see how far the earlier results were confirmed. The second and third examinations were not necessarily made at the same points of the bronchus, as the points of the original measurements were not marked; but they give some idea of the range of results obtained by the same observer on a re-examination.

A swab was taken from the surface of the bronchus from 30 of the operation specimens and culture made for bacteria on blood-agar plates, which we:e read at 48 hours.

\section{RESULTS}

Table II shows the results of the first part of this study, the bronchi being grouped according to the disease from which the patient suffered.

Controls. - The controls show no evidence of either hypertrophy or atrophy with age.

Chronic Bronchitis. - In all cases both the gland layer and the wall between the epithelium and the cartilage were increased in thickness beyond the normal. As the bronchial wall suffers practically the same absolute increase in thickness as the gland (wall-4.4 to 7.4 ; gland -1.2 to 4.4$)$, it is clear that the increased thickness of the wall is almost wholly attributable to the gland thickening, which also accounts for the increase in gland/wall ratio (from 0.26 to 0.59 ). Moreover, there is no overlap between the results in this group and the normal, for the maximum thickness of the normals is well below the minimum for the bronchitic group and altogether, therefore, the difference in results for the whole group as compared with the normal group is highly significant.

Table III gives the results for main, lobar, and segmental bronchi, showing no significant difference between them. As these bronchi were chosen at random, it is fair to assume that in main, lobar, and segmental bronchi hypertrophy of glands is widespread.

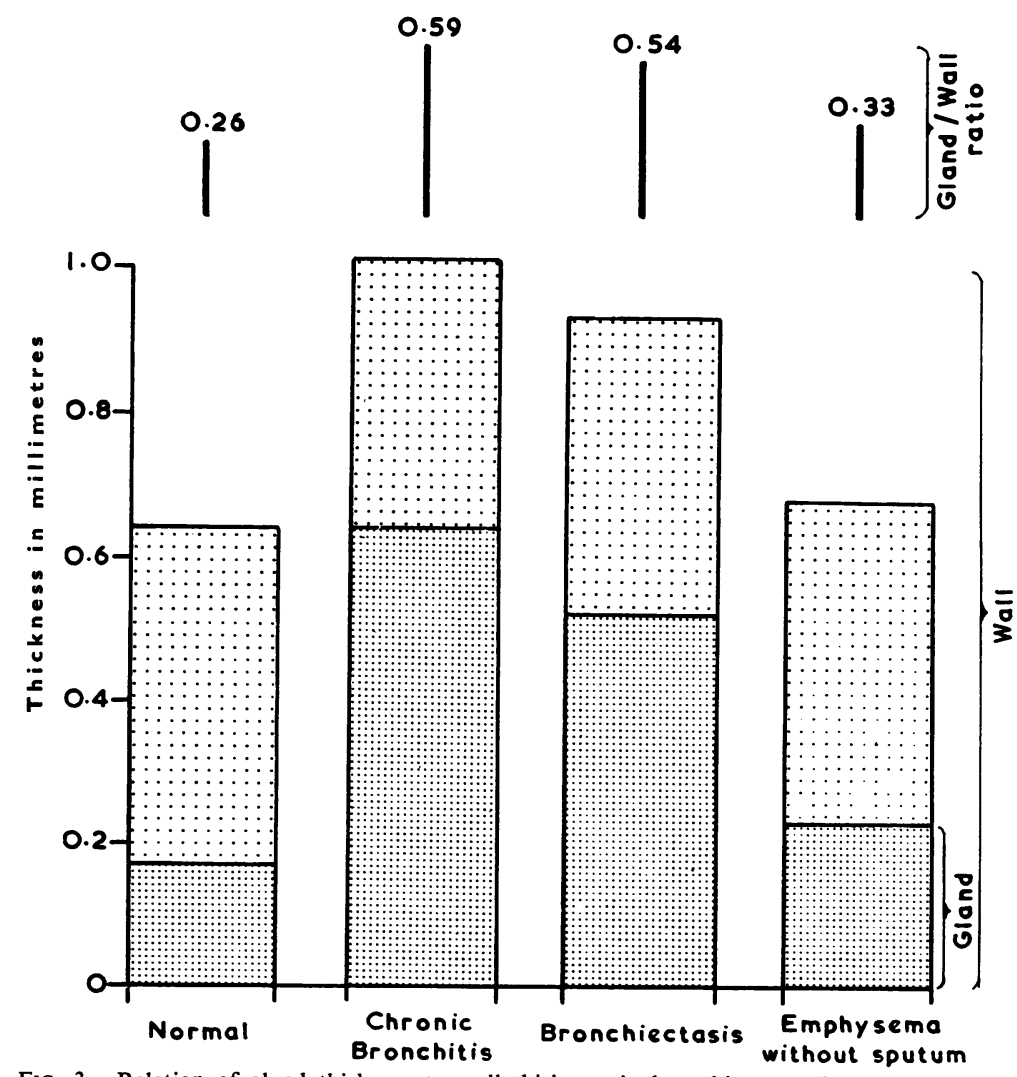

FIG. 3.-Relation of gland thickness to wall thickness in bronchi grouped by reference to clinical diagnosis (Table II). 
TABLE III

RESULTS IN MAIN, LOBAR, AND SEGMENTAL BRONCHI IN CHRONIC BRONCHITIS

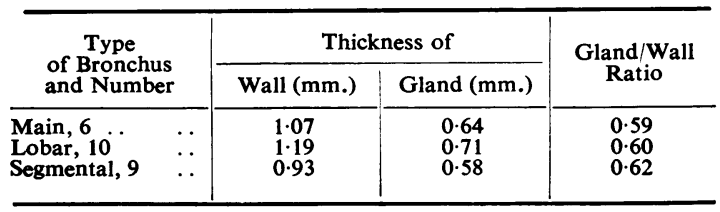

In 12 of the 20 patients whose sputum could be accurately measured in hospital, there was correlation between the amount produced and gland thickness. In the group whose sputum production was $1 \mathrm{oz}$. a day the mean gland thickness was $0.52 \mathrm{~mm}$., the gland/wall ratio 0.53 , while in patients producing $6 \mathrm{oz}$. the gland measurement was $0.70 \mathrm{~mm}$. and the ratio 0.76 .

The considerable increase in depth of gland represents an even more striking increase in volume. As in a subject with chronic bronchitis the glands make a more compact and complete layer than in the normal, it is probable that there is an increase not only in thickness but in length and width also; if gland increase were the same in all directions, the nearly fourfold increase from 1.2 to 4.4 would result in an overall increase of sixty-four-fold. But whatever these increases are, as the normal volume of glandular tissue is so much greater than that of goblet cells, it is clear that the glands are the more significant volumetrically.

Taking the mean of the counts of the number of acini, a count of 20 per high-power field was found in most cases to distinguish normal bronchi from those of patients with chronic bronchitis. For example, although the mean in the normal was more than 20 , two of 13 separate counts fell below. The average in chronic bronchitis was 14 as compared with 24 in the normal. This decrease is due partly to the increase in size of the acini, but, if dilatation alone were responsib!e for the increase in gland layer thickness, the decrease in acini would be even greater than in fact it is, which suggests that both hyperplasia as well as hypertrophy has supervened.

Characteristics of Gland Hypertrophy.The glands of the cases of chronic bronchitis show a great increase in the number of mucous cells relative to serous cells, but although nearly all cells were distended with mucus it is still possible to find occasional ones in which only granules are visible. The other striking feature is the way the acini lie close together with relatively little inflammatory cell infiltration and very little fibrosis.
This lack of infiltration was all the more remarkable as it was seen even when more peri올 pheral parts of the bronchial tree were plugged with pus, and tiny, but acute, abscesses haff destroyed bronchiolar walls. This group did no $\mathbb{D}$ show the atrophy and fibrosis of acini, which oftery form part of the picture of damage resulting from irradiation or from ulceration of the bronchus, as in tuberculosis, or inflammation distal to an obstruction.

In the epithelium the degree of hypertrophy of goblet cells varied widely, particularly in the bronchioles, where sometimes, within one section several square centimetres in area, the lining consisted almost entirely of goblet cells, while others again showed only an occasional one.

For purposes of diagnosing chronic bronchitis, a single section of a main or lobar bronchus is more dependable than one including bronchioles and small bronchi.

On these simple measurements it is possible to make a clear distinction between bronchi from "normal" subjects and those from subjects suffering from chronic bronchitis. The upper limit of normal gland thickness is $0.36 \mathrm{~mm}$., of its ratio to wall is 0.36 , and the lower limit of acing̋ in a field of $0.425 \mathrm{~mm}$. diameter is 20 .

CONFIRMATION of Results.-The above results $\overrightarrow{5}$ were confirmed by means of repeat counts made some weeks apart on nine bronchi taken a random from 25 in the chronic bronchitic group? the analysis of which is shown in Appendix B The variation in results on different occasions is so small that the problem of distinguishing bronchitis from normal patients is not materially? affected.

BRONCHIECTASIS. - The averages for this group are significantly different from the normal, but unlike the results from cases of chronic bronchitis? the figures show a slight overlap with the controls $\frac{\text { D }}{2}$ This is not perhaps surprising, considering the range in the amount of sputum produced by subjects in this group.

In bronchiectasis the characteristic appearance is somewhat different from that in bronchitis, as there was often considerable interacinar fibrosise and infiltration with inflammatory cells. Thus the reduction in the relative number of acini in a high power field is not due merely to increase in their size but to their separation by fibrous tissue.

Of the two patients whose measurements camed within the normal range, one, a girl of 19 , produced? hardly any sputum, while the other, according to̊ his report, had been producing up to $2 \mathrm{oz}$. a daye in recent years. 

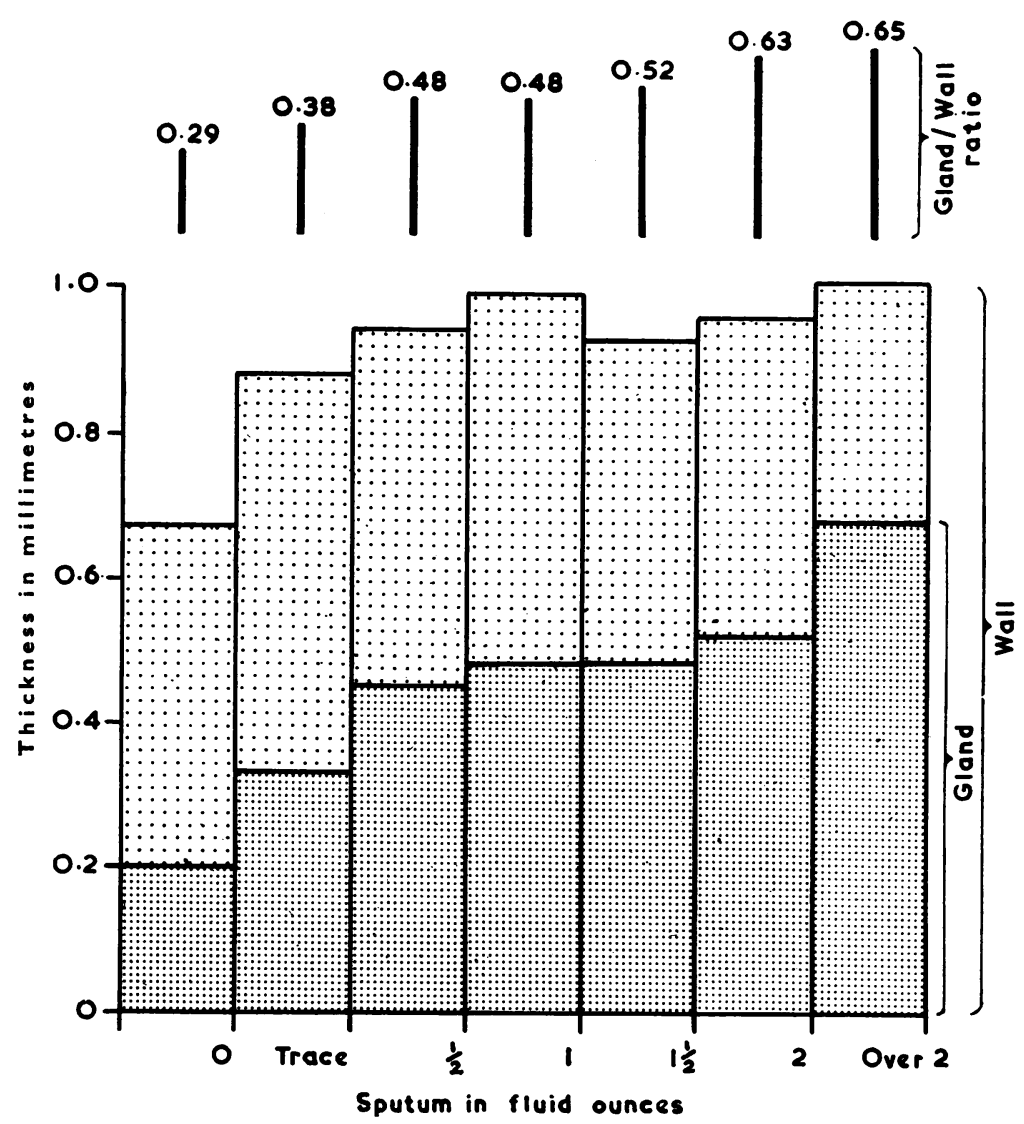

Fig. 4.-Relation of gland thickness to wall thickness in bronchi grouped according to sputum production (Table IV).

EMPHYSEMA.- - The study included a small group of three patients in whom emphysema without sputum was diagnosed clinically and confirmed pathologically. This is the type of emphysema to which such names as primary, essential, and idiopathic are applied. There was in them no significant difference in gland measurement from the normal. In none of these subjects was there more than an " occasional " piece of sputum, even at the time of operation or death. A further case, of unilateral emphysema, was at first included on the grounds that his history showed freedom from sputum; however, closer investigation disclosed that this had been true many years earlier when he was first seen, but that by the time he came to operation in middle age he was producing half a cupful of sputum a day. The measurements of the glands and wall of the bronchus of the resected lung fell within the range of chronic bronchitis.

Thus, although for a long time emphysema may predominate clinically a patient may later produce sputum, suggesting that the emphysema did not derive from chronic bronchitis. Such patients are, however, often classed "chronic bronchitis and emphysema" and are accordingly lost in that general category.

RANDOM SPECIMENS.-Statistical analysis of the measurements in this group (Table IV) shows that gland hypertrophy is associated with production

\section{TABLE IV}

BRONCHI FROM OPERATION CASES GROUPED ACCORDING TO AMOUNT OF SPUTUM

\begin{tabular}{|c|c|c|c|c|c|c|c|}
\hline & \multicolumn{7}{|c|}{ Sputum (Fluid Ounces) } \\
\hline & Nil & Trace & $\frac{1}{2}$ & 1 & $1 \frac{1}{2}$ & 2 & $>2$ \\
\hline $\begin{array}{l}\text { No. of cases } \\
\text { Thick̈ness of : }\end{array}$ & $\begin{array}{l}5 \\
6\end{array}$ & $\begin{array}{l}10 \\
14\end{array}$ & $\begin{array}{r}9 \\
14\end{array}$ & $\begin{array}{l}4 \\
6\end{array}$ & $\begin{array}{l}3 \\
4\end{array}$ & $\begin{array}{l}4 \\
6\end{array}$ & $\begin{array}{l}2 \\
4\end{array}$ \\
\hline $\begin{array}{l}\text { Wall (mm.) } \\
\text { Gland , } \\
\text { Gland/wail ratio } \\
\text { Acini } / 0 \cdot 36 \mathrm{~mm} \text {. } \\
\text { field }\end{array}$ & $\begin{array}{c}0 \cdot 67 \\
0 \cdot 20 \\
0 \cdot 29 \\
\\
25\end{array}$ & $\begin{array}{c}0.88 \\
0.33 \\
0.38 \\
20\end{array}$ & $\begin{array}{c}0.94 \\
0.45 \\
0.48 \\
\\
19\end{array}$ & $\begin{array}{l}0.99 \\
0.48 \\
0.48 \\
16\end{array}$ & $\begin{array}{c}0.93 \\
0.48 \\
0.52 \\
18\end{array}$ & $\begin{array}{c}0.96 \\
0.57 \\
0.63 \\
16\end{array}$ & $\begin{array}{c}1 \cdot 16 \\
0.68 \\
0.65 \\
14\end{array}$ \\
\hline & 25 & 20 & 19 & 16 & 18 & 16 & 14 \\
\hline
\end{tabular}


of sputum and that the degree of hypertrophy varies directly with the amount of sputum produced. Results in Table $\mathrm{V}$ show that in general any increase in wall thickness is due to an increase in gland thickness.

TABLE V

COMPARISON OF INCREASE IN THICKNESS OF WALL AND GLAND

\begin{tabular}{|c|c|c|c|c|}
\hline \multirow{2}{*}{$\begin{array}{c}\text { Sputum } \\
\text { Groups as } \\
\text { in Table IV } \\
\text { (fluid } \\
\text { ounces) }\end{array}$} & \multicolumn{2}{|c|}{ Gland } & \multicolumn{2}{|c|}{ Wall } \\
\hline & $\begin{array}{c}\text { Thickness* } \\
\text { (mm.) }\end{array}$ & $\begin{array}{c}\text { Difference } \\
\text { from Norma } \\
(0 \cdot 17)\end{array}$ & $\begin{array}{c}\text { Difference } \\
\text { from Normal } \\
(0.64)\end{array}$ & $\begin{array}{c}\text { Thickness } \\
\text { (mm.) }\end{array}$ \\
\hline $\begin{array}{c}\text { Nil } \\
\text { Trace }^{\frac{1}{2}} \\
1^{\frac{1}{2}} \\
2^{\frac{1}{2}} \\
>2\end{array}$ & $\begin{array}{l}0.20 \\
0.33 \\
0.45 \\
0.48 \\
0.48 \\
0.57 \\
0.68\end{array}$ & $\begin{array}{l}0.3 \\
0.16 \\
0.28 \\
0.31 \\
0.31 \\
0.40 \\
0.51\end{array}$ & $\begin{array}{l}0.3 \\
0.24 \\
0.30 \\
0.35 \\
0.29 \\
0.32 \\
0.52\end{array}$ & $\begin{array}{l}0.67 \\
0.88 \\
0.94 \\
0.99 \\
0.93 \\
0.96 \\
1.16\end{array}$ \\
\hline
\end{tabular}

* The similarity between the increase in gland thickness and wal thickness (columns 2 and 3 ) suggests that the latter mainly arises from the gland hypertrophy.

The measurements of the bronchi found in the lowest sputum category of subjects with chronic bronchitis correspond to those random operation specimens with $1 \mathrm{oz}$. or more of sputum and the findings in these bronchi support the findings in the groups of chronic bronchitis.

The sharp increase in the figures from nil to $\frac{1}{2} \mathrm{oz}$. as compared with the figures for the fourth, fifth, and sixth columns in Table IV suggests that the amount of secretion above the normal must be considerable before even a trace of sputum is coughed up. The rate of increase in gland thickness between the nil and $\frac{1}{2} \mathrm{oz}$. sputum group is much steeper than the increase which accompanies an equivalent sputum rise in groups with larger sputum production, suggesting that secretion is increased considerably before sputum is produced. With gross gland hypertrophy sputum production is always established.

SMoKING.-The subjects in the random group were divided broadly on habits of the previous 10 years into those who smoked less than 20

TABLE VI

EFFECT OF SMOKING ON GLAND/WALL RATIOS

\begin{tabular}{|c|c|c|c|}
\hline & \multicolumn{3}{|c|}{ Sputum Groups* (Fluid Ounces) } \\
\hline & Nil, Trace & $\frac{1}{2}-1$ & $1 \frac{1}{2}-2->2$ \\
\hline $\begin{array}{l}\text { Smoking: } \\
\text { Less than } 20 \text { cigarettes } \\
\text { a day } \\
20 \text { or more a day } \quad . .\end{array}$ & $\begin{array}{l}(6) \dagger 0.33 \\
(8) \quad 0.36\end{array}$ & $\begin{array}{l}\text { (5) } 0.51 \\
\text { (6) } 0.43\end{array}$ & $\begin{array}{l}\text { (4) } 0.58 \\
\text { (4) } 0.58\end{array}$ \\
\hline
\end{tabular}

* The seven groups used in Table IV are here grouped into three.

$\dagger$ The figures in brackets are the number of cases. cigarettes a day and those who smoked 20 or more. There is no material difference between the two. While not precluding that smoking in the community may be associated with sputum? production, the figures suggest that, within a group producing the same amount of sputum, thicknesse of the gland layer does not vary with smokinghabits. The numbers are too small to warrant: further analysis.

Culture OF BRONCHI.-Cultures from all bronchi were sterile. Although patients usually $\vec{x}$ receive some antibiotic drug for at least 24 hours $\vec{G}$ before operation, this result seemed surprising, $\sim$ seeing that all of them had some disease and had $\vec{\omega}$ received anaesthetic, and some habitually produced $N$ sputum.

\section{Discussion}

The fundamental change in the lung in chronic $\overparen{\Phi}$ bronchitis is hypertrophy of mucus-secreting $\vec{\varphi}$ structures-glands and goblet cells (Reid, 1954, 8 $1958 \mathrm{~b}$ ) - the clinical manifestation of which is sputum production. Hypersecretion of mucus being an accentuation of normal function rather than an aberration the demarcation retween normal and abnormal is thus quantitative. In the $\frac{\circ}{\Phi}$ search for diagnostic criteria the glands have, for $\stackrel{\varrho}{\rightarrow}$ several reasons, proved more satisfactory than the $\overrightarrow{0}$ goblet cells. Whereas the changes in large bronchi 3 have been shown to be very constant, the epithelium of all bronchioles is not necessarily affected by goblet cell increase ; in routine post-mortem and surgical material the epithelium is often unsatisfactory for detailed examination, particu- $x$ larly as associated infection more often damages $\frac{5}{3}$ the epithelium than the glands; measurement of gland thickness and of the number of acini is $\frac{0}{3}$ easier than counting the necessarily large numbers of individual cells; moreover, even if goblet cells $\frac{0}{\partial}$ were to line the whole of the bronchial tree their volume would still be less than the volume of gland tissue in the normal bronchial wall, which No suggests that the glands are quantitatively the important factor in sputum production.

In their examination of the lungs from six cases $\underset{\omega}{N}$ of bronchial asthma, Huber and Koessler in 1922 ? carried out a series of measurements of the 0 bronchial wall, their main interest being increase $\Phi$ in its absolute thickness and the contribution to ? this of the muscle layer. Some measurements of 0 glands were made, but the authors concluded that, " as the gland system is present inside, outside, $\stackrel{\square}{\stackrel{Ð}{\oplus}}$ and between the edges of the cartilaginous plaques, $\stackrel{\unrhd}{\unrhd}$ no adequate system of measurement could be devised to determine the actual increase due to 
gland changes." Comparison is made additionally difficult by the inclusion of examples of allergic asthma and asthmatic bronchitis.

The measurements here described, of the mucous glands in the bronchial wall, provide a convenient method of assessing gland hypertrophy and can easily be made on routine examination. Where measurements diverge from the normal, they not only point to the presence of the disease but, since the degree of hypertrophy reflects the amount of sputum produced, they give some indication of its severity. By the use of a graticule set into the eyepiece of the microscope accurate measurements of gland thickness were obtained, but a rough estimate of the gland/wall ratio can be made without precise measurement and, together with a count of the number of acini, often suffices for diagnosis.

Any histological means of diagnosing chronic bronchitis will enable the disease to be distinguished more precisely from asthma and from emphysema without chronic bronchitis. Certain features in some well-established cases of chronic bronchitis may make it difficult to distinguish it clinically from asthma. Some authorities would place both in one nosological group, but this is undesirable, as not only are the clinical differences between the two diseases blurred thereby, but the critical study of the difficult intermediate conditions is seemingly rendered less important. Chronic bronchitis is characterized by the habitual production of mucoid sputum, "uncomplicated" or spasmodic asthma by spasmodic dyspnoea, relieved by antispasmodic drugs, with no habitual sputum. While some patients may present both conditions, more often and more importantly they do not. Houston, De Navasquez, and Trounce (1953) give a valuable report on cases of " uncomplicated asthma," in which, to judge from the histories, there was no habitual production of sputum and which, therefore, are not clinically confusing. On microscopic examination "no quantitative or qualitative abnormality could be detected in the mucous glands": the ciliated epithelium was detached from the wall of the bronchial tree, in which goblet cells could be recognized; but, although "it was not possible to decide whether they were increased or not," the large number of goblet cells, as described by Hilding (1943) in the United States of America, was not apparent. This finding would appear to be confirmed by the conclusion of this paper that there is no high degree of gland hypertrophy without habitual sputum production. It would seem then that neither gland hypertrophy nor any great increase in goblet cells is a constant feature of asthma.

Probably in North America many patients presenting with wheeze, cough, and sputum production are labelled asthmatic who in this country would be called chronic bronchitic. Hilding in the United States reports in 12 of 31 cases of fatal asthma a " metamorphosis of ciliated cell to goblet cell "throughout the epithelium of the bronchial tree. Houston and his colleagues could not confirm this, and it is likely that Hilding was referring to what in this country would be termed chronic bronchitis. It may well be that goblet cell hypertrophy may occur in spasmodic asthma without gland hypertrophy, but it is reasonable to assume that the patients in this country who are grouped as "chronic bronchitic" are numerous as compared with the same group in the United States because in that country some, at least, are included in the group labelled " asthmatic."

Definitions are to some extent arbitrary. For instance, several definitions of chronic bronchitis given recently have included some disability as well as cough and sputum ; Oswald (1958) included shortness of breath, and Higgins, Oldham, Cochrane, and Gilson (1956) in their survey required a history of incidents of infection. The purpose of an epidemiological survey may largely influence the limits of the definition. But, the basic lesion being hypertrophy of mucus-secreting structures, if the important early stages of the disease are to be studied before disability has supervened, the significance of cough and sputum by themselves must be accepted. Stuart-Harris (1954) formulated criteria based on these while distinguishing those with shortness of breath. Ogilvie and Newell (1957) in his survey of bronchitis in Newcastleupon-Tyne set his definition to include mild stages of the condition.

The difficulty, then, is to decide what amount of sputum is significant.

This investigation indicates that small amounts of sputum produced habitually, often dismissed as unimportant, as a mere manifestation of smoker's cough, may represent a quite disproportionate degree of hypertrophy of mucous glands. In studying the natural history of bronchitis it is thus certainly desirable to include this mild stage of the disease.

The criteria described here make possible a reasonably certain pathological diagnosis of chronic bronchitis. Its very basis, however, mucous gland hypertrophy, points to the need for discovering the conditions which produce this 
state and for understanding the interaction of hypersecretion with infecting organisms, to produce further increase in secretion or damage to the respiratory part of the lung.

\section{SUMmary}

In the search for a yardstick for the histological diagnosis of chronic bronchitis the glands rather than the goblet cells were chosen, chiefly because they are volumetrically more important (volume of the order of 40 times greater).

A clear distinction between normal bronchi and those from subjects with chronic bronchitis is possible using the gland/wall thickness ratio as the yardstick, measurements being made at a point between cartilage and epithelium, plus a count of the number of gland acini included in a microscopic field of $0.36 \mathrm{~mm}$. diameter.

Measurements in cases of emphysema without sputum fell within normal range; those in cases of bronchiectasis have a mean value within the range for chronic bronchitis but overlap with normal values.

Much the same correlation between hypertrophy of gland layer and amount of sputum, particularly of lesser amounts of sputum than those produced by patients diagnosed clinically as chronic bronchitics, was found after similar measurements had been made on bronchi from random operation stumps. The degree of gland hypertrophy in patients producing small amounts of sputum suggests that sputum is produced only after a considerable increase in secretion.

I should like to thank Sir Clement Price Thomas, Sir Russell Brock, Mr. N. R. Barrett, Mr. O. S. Tubbs, and Mr. W. P. Cleland, and also Dr. J. W. Clegg and Dr. K. F. W. Hinson, of the Brompton Hospital, for access to surgical material, and Dr. D. Teare for sending me some of the normal lungs; Dr. U. G. Bucher, who was responsible for the early stages of the study of bronchi from operation specimens, including their culture; and Dr. R. W. Riddell, who provided technical facilities for the latter in the Bacteriological Department, Brompton Hospital.

\section{REFERENCES}

Florey, H., Carleton, H. M., and Wells, A. Q. (1932). Brit. J. exp. Path., 13, 269.

Higgins, I. T. T., Oldham, P. D., Cochrane, A. L., and Gilson, J. C. (1956). Brit. med. J., 2, 904.

Hilding, A. C. (1943). Ann. Otol. (St. Louis), 52, 5.

Hilding, A. C. (1943). Ann. Otol. (St. Louis)

Houston, J. C., De Navasquez, S., and Trounce, J. R. (1953). Thorax, $8,207$.

Huber, H. L., and Koessler, K. K. (1922). Arch. intern. Med., 30, 689. Ogilvie, A. G., and Newell, D. J. (1957). Chronic Bronchitis in Newcastle-upon-Tyne. Livingstone, Edinburgh and London. swald, N. C. (1958). Recent Trends in Chronic Bronchitis. LloydLuke, London.

Reid, L. (1954). Lancet, 1, 275.

Reid, (1958a). Postgrad. med. J., 34, 24.
Reid, L. (1958b). "The Pathology of Chronic Bronchitis." In Recent Trends in Chronic Bionchitis, p. 26, edited by N. C. Oswald. Lloyd-Luke, London.

(1960). In Lectures on the Scientific Basis of Medicine. " Chronic Bronchitis and Hypersecretion of Mucus." In the press.

Stuart-Harris, C. H. (1954). Brit. J. Tuberc. Dis. Chest, 48, 169.

A P P E N DIX A

Estimate of Relative Volume of Glands and Goblet Cells

The relative volumes of glandular tissue and goblet cells were estimated approximately for trachea, mainc bronchi, and as far as the fifth order or generation? of intrasegmental bronchi. This part of the bronchial, tree was represented as a tube $24 \mathrm{~cm}$. long (trachea $10 \mathrm{~cm}$. ; length along main bronchus and branches as far as fifth generation of basal bronchus of the right lower lobe, $14 \mathrm{~cm}$.). Hilding and Hilding (1948) studied the circumference of the branches of theo bronchial tree at different levels, and from their diagrams it can be deduced that at the fifth generation of intrasegmental bronchi the summated diameter of all bronchi is between two and three times that of the trachea.

The diameter used to estimate the circumferenceo of the representative "tube" was the mean of the diameter of the trachea $(2.0 \mathrm{~cm}$.) and the dista? diameter $(6 \mathrm{~cm}$.), that is, $4 \mathrm{~cm}$. The wall area of such as tube $\pi \times$ diameter $\times$ length $=3.17 \times 4 \times 24=304.32 \mathrm{~cm} .{ }^{2} \frac{\partial}{D}$ i.e., $300 \mathrm{~cm} . "$ approximately. The goblet cells are an average of one in four of the epithelial cells in theo main bronchi in the adult. On the assumption tha this was the concentration throughout, and that the height of a goblet cell is $20 \mu(0.002 \mathrm{~cm}$.), the volume of the goblet cells was estimated to be $\frac{300}{4} \times 0.002 \mathrm{~m}$ $=0.15 \mathrm{ml}$.

The glands in the normal bronchus do not come pletely surround the circumference but lie both interna to the plates of cartilage, between them, and even external to them. For the purpose of this calculation they were assumed completely to surround the bronch and to be of the depth of the inner layer between cartilage and epithelium, $0.17 \mathrm{~mm}$., say $0.2 \mathrm{~mm}$. The volume of glands is therefore $300 \times 0.02=6 \mathrm{ml}$., i.e. $\frac{\text { 을 }}{2}$ 40 times greater than that of the goblet cells.

\section{A P P E N D I X B}

\section{Confirmation of Results by Repeat} MEASUREMENTS

The following table shows the analysis of measure ments made some weeks apart on a group of bronchio not necessarily at the same point in the circumferences of the bronchus. "Measurement" refers to the single set of readings, namely, gland and wall thickness and the ratio derived from the "count " to the mean of the measurements of a bronchus taken on ons occasion. Intercount variance is very small, and, a£ it is much smaller than intermeasurement variance oP the variance between specimen and specimen, it doe $\$$ not materially affect distinction of bronchitic frome normal specimens. 


\begin{tabular}{|c|c|c|c|c|c|c|c|c|c|}
\hline \multirow{2}{*}{ Specimen } & \multirow{2}{*}{\multicolumn{2}{|c|}{$\begin{array}{l}\text { "Count" and } \\
\text { (No. of Wall Gland } \\
\text { Measurements at } \\
\text { Each Count) }\end{array}$}} & \multicolumn{2}{|c|}{ Mean Thickness } & \multirow{3}{*}{$\begin{array}{c}\begin{array}{c}\text { Mean } \\
\text { Wall/Gland } \\
\text { Ratio }\end{array} \\
0.52 \\
0.53 \\
0.54\end{array}$} & \multirow{3}{*}{$\begin{array}{c}\begin{array}{c}\text { Standard } \\
\text { Ratios in } \\
\text { Different } \\
\text { Counts }\end{array} \\
0.01\end{array}$} & \multirow{3}{*}{$\begin{array}{c}\begin{array}{c}\text { Deviation } \\
\text { of Ratio } \\
\text { Measurements } \\
\text { in One Count }\end{array} \\
0.08 \\
\overline{0.05}\end{array}$} & \multirow{3}{*}{$\begin{array}{c}\text { Standard Error } \\
\text { of Mean Ratios } \\
\text { (Counts Averaged } \\
\text { for Each Specimen) }\end{array}$} & \multirow{3}{*}{$\begin{array}{l}\text { Acin } \\
22 \\
22 \\
22\end{array}$} \\
\hline & & & \multirow{2}{*}{$\begin{array}{c}\begin{array}{c}\text { Wall } \\
(\mathrm{mm} .)\end{array} \\
0.99 \\
0.96 \\
1.00\end{array}$} & \multirow{2}{*}{$\begin{array}{c}\begin{array}{c}\text { Gland } \\
(\mathrm{mm} .)\end{array} \\
0.51 \\
0.51 \\
0.55\end{array}$} & & & & & \\
\hline $\mathbf{A}$ & II & $\begin{array}{l}\text { (2) } \\
\text { (1) } \\
\text { (2) }\end{array}$ & & & & & & & \\
\hline B & II & $\begin{array}{l}(2) \\
(1) \\
(1)\end{array}$ & $\begin{array}{l}0.77 \\
0.94 \\
0.77\end{array}$ & $\begin{array}{l}0.55 \\
0.58 \\
0.55\end{array}$ & $\begin{array}{l}0.71 \\
0.62 \\
0.72\end{array}$ & 0.05 & ב & & $\begin{array}{l}20 \\
15 \\
20\end{array}$ \\
\hline C & $\begin{array}{r}\text { II } \\
\text { III }\end{array}$ & $\begin{array}{l}(5) \\
(3) \\
(1)\end{array}$ & $\begin{array}{l}0.83 \\
0.94 \\
0.83\end{array}$ & $\begin{array}{l}0.30 \\
0.41 \\
0.36\end{array}$ & $\begin{array}{l}0.44 \\
0.43 \\
0.44\end{array}$ & 0.01 & $\begin{array}{c}0.06 \\
0.09 \\
-\end{array}$ & & $\begin{array}{l}18 \\
13 \\
17\end{array}$ \\
\hline $\mathbf{D}$ & II & $\begin{array}{l}\text { (2) } \\
\text { (1) }\end{array}$ & $\begin{array}{l}1.48 \\
1.20\end{array}$ & $\begin{array}{l}0.75 \\
0.58\end{array}$ & $\begin{array}{l}0.51 \\
0.48\end{array}$ & 0.02 & 0.01 & & $\begin{array}{l}18 \\
16\end{array}$ \\
\hline $\mathbf{E}$ & II & $\begin{array}{l}(2) \\
(3)\end{array}$ & $\begin{array}{l}0.99 \\
1.06\end{array}$ & $\begin{array}{l}0.51 \\
0.68\end{array}$ & $\begin{array}{l}0.52 \\
0.63\end{array}$ & 0.07 & $\begin{array}{l}0.18 \\
0.08\end{array}$ & & $\begin{array}{l}14 \\
13\end{array}$ \\
\hline $\mathbf{F}$ & II & $\begin{array}{l}\text { (4) } \\
\text { (1) }\end{array}$ & $\begin{array}{l}1 \cdot 13 \\
1 \cdot 13\end{array}$ & $\begin{array}{l}0.55 \\
0.55\end{array}$ & $\begin{array}{l}0.48 \\
0.48\end{array}$ & 0 & $\begin{array}{c}0.06 \\
-\end{array}$ & & $\begin{array}{l}17 \\
17\end{array}$ \\
\hline$G$ & II & $\begin{array}{l}\text { (3) } \\
\text { (I) }\end{array}$ & $\begin{array}{l}0.90 \\
0.88\end{array}$ & $\begin{array}{l}0.52 \\
0.51\end{array}$ & $\begin{array}{l}0.61 \\
0.57\end{array}$ & 0.03 & $\begin{array}{c}0.15 \\
-\end{array}$ & & $\begin{array}{l}13 \\
13\end{array}$ \\
\hline $\mathbf{H}$ & II & $\begin{array}{l}\text { (3) } \\
\text { (1) }\end{array}$ & $\begin{array}{l}0.62 \\
0.62\end{array}$ & $\begin{array}{l}0.33 \\
0.33\end{array}$ & $\begin{array}{l}0.52 \\
0.53\end{array}$ & 0.01 & $\begin{array}{c}0.20 \\
-\end{array}$ & & $\begin{array}{l}19 \\
19\end{array}$ \\
\hline $\mathbf{I}$ & II & $\begin{array}{l}(2) \\
\text { (1) }\end{array}$ & $\begin{array}{l}2.03 \\
2.03\end{array}$ & $\begin{array}{l}1 \cdot 38 \\
1 \cdot 38\end{array}$ & $\begin{array}{l}0.69 \\
0.67\end{array}$ & 0.01 & $\begin{array}{c}0.06 \\
-\end{array}$ & & $\begin{array}{l}13 \\
13\end{array}$ \\
\hline Pooled valu & $\cdots$ & $\ldots$ & & & & 0.03 & $0 \cdot 10$ & 0.08 & \\
\hline
\end{tabular}

